\title{
SUSTAINABILITY OF MICRO HYDRO PROJECTS IN LALITPUR DISTRICT, NEPAL
}

\author{
Ramesh Ranabhat ${ }^{1}$, Prabesh Paudyal ${ }^{2}$ \\ ${ }^{1}$ Mechannical Department, Institute of Engineering, Pulchowk Campus, T. U., Nepal \\ Email Address: ramesh.ranabhat@,ioe.edu.np \\ ${ }^{2}$ UNHCR, Damak, Jhapa \\ Email Address: paudyal@unher.org
}

\begin{abstract}
Energy is one of the important necessities of the society and basic for sustainable development. The demand of electricity is increasing. Micro hydro power plants are one of the effective tools to provide rural household with energy in Nepal. These plants are also provided with government subsidies. Energy is produced by the water current from micro hydro stations. There are water availability changes due to the climatic changes and other non climatic changes; this has made water very scarce. There are few studies done in water availability and energy and even less in operator level. This study focuses in Lalitpur district in Bagmati zone, Nepal. There is lack of interlink study of the different water uses like irrigation, drinking water, animal husbandry water use etc which affects water availability. Integrating interdisciplinary water planning in energy development is one of the important steps to increase the sustainability of micro hydro plants. The operators working in micro hydro plants have already perceived the change in water availability. Thus it is important to plan the water resources using the operator's local knowledge and situation to cope with increasing demand of electricity and the impacts of decreasing water resources.
\end{abstract}

Keywords: energy, micro hydro, demand, sustainable development, subsidy

\section{Introduction}

"Energy is central to sustainable development and poverty reduction efforts" (UNDP). In all countries it is the fundamental requirement for providing other basic life necessities such as food, water, shelter and clothing. Without energy, society is unable to maintain or improve living standards, meet the basic needs of citizens or maintain the socioeconomic infrastructure necessary for political and economic stability. The accomplishments of civilization have largely been achieved through the increasingly efficient and extensive harnessing of various forms of energy to extend human capabilities and ingenuity (Rogner \& Popescu). Energy is crucial to achieve all the eight Millennium Development Goals (MDGs). It is derived from the different fuel resources which are grouped into different categories based on the fuel characteristics, monetization, resources availability, dependency etc. Total annual energy consumption of Nepal is 401 Million GJ (WECS). It will be used for lighting, cooking, heating and transporting purposes. Nepal's energy resources are broadly divided into three categories: Traditional, Commercial and Alternative. It is endowed with good renewable energy potential. The major sources of renewable energy are hydropower, solar energy, various forms of biomass energy, biogas and wind energy etc. Despite huge renewable energy potential still around $85 \%$ of the total final energy consumption in Nepal is met by traditional biomass and only $56 \%$ of households in Nepal have access to electricity. Majority of people in Nepal are living in rural areas and are poor. It is not possible to significantly improve the living standard of the rural poor if their demand for clean energy services is not met. Extension of national grid to reach those areas is not possible in many years to come due to the difficult terrain, high cost and also there is an enormous 
energy crisis in the country. Therefore, clean and sustainable energy such as renewable energy technologies are the solutions (RE Subsidy policy 2013). The Fig 1.1 below is the total installation of Renewable Energy Technologies in Nepal till 2012. It illustrate the rural electrification through micro-hydro is a credible option for Nepal since the country has exploited only 2 percent of its economically potential power.

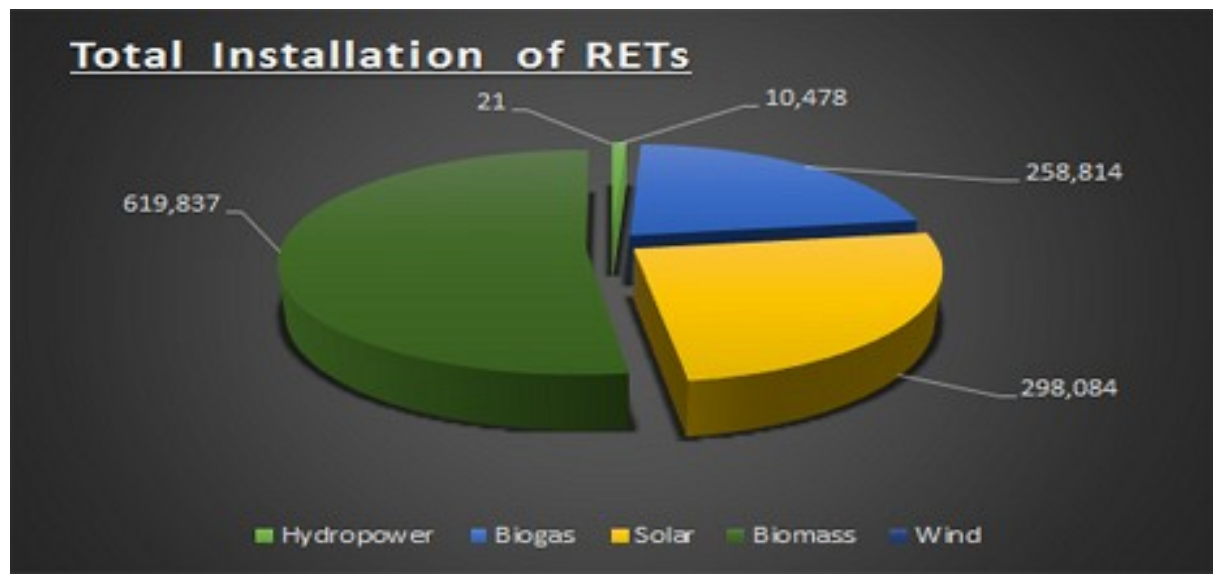

Fig 1.1 Total installations of Renewable Energy Technologies (Source: AEPC-2012/13)

The difficulties has been experienced in rapid extension of the National Grid for rural electrification due to remote topography, dispersed settlement pattern and the limited financial resources of the Government of Nepal (Rural Energy Policy, 2006). To facilitate the rural people to benefit from the energy usage, the construction of the micro hydro power are chosen. The micro hydro is attracting lots of funds under $\mathrm{CDM} /$ renewable clean energy and its execution is becoming very easy due its history of above 30 years. The construction of micro hydro projects in Nepal is in increasing trend, particularly in districts that has not been integrated with the national grid. Figure 1.2 point up the rapid increasing rate of the micro- hydro plants.

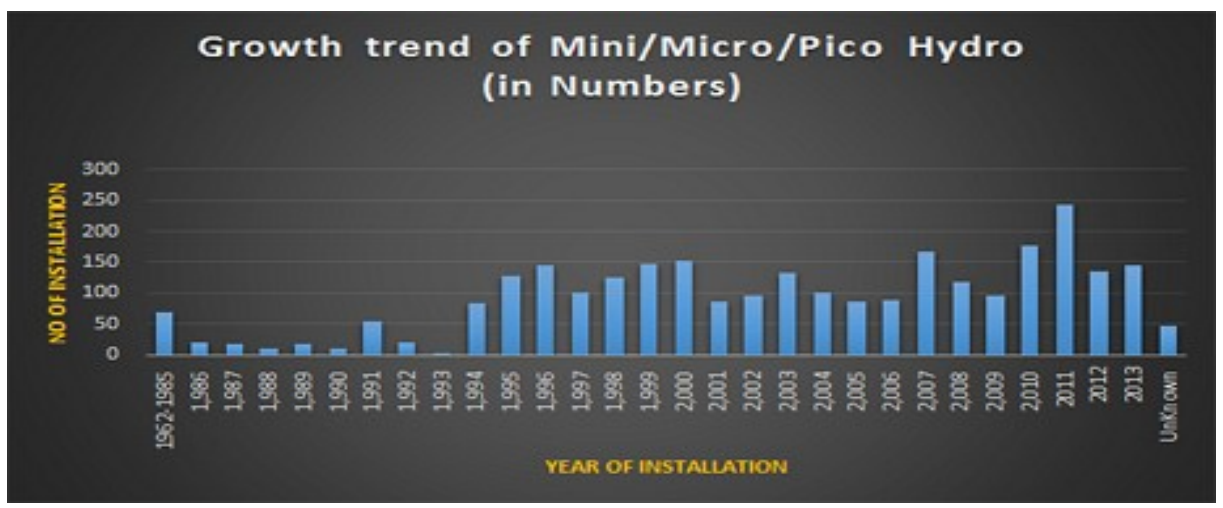

Fig 1.2 Growth trend of Mini/Micro/Pico Hydro (Source: AEPC-2012/13)

The construction and its studies are done by Alternate Energy Promotion Centre (AEPC), established in 1996 under the Ministry of Science and Technology. The centre is implementing alternative energy programs including development of micro hydro power with aid from different donor agencies. Other government body like DDC also subsidizes costs for micro hydro power projects. The main objective of AEPC is to promote and disseminate renewable/alternative energy technologies and meet basic energy needs of rural people in the country. For the promotion of alternative energy, AEPC also provides subsidies to enthusiastic micro hydropower developers through its interim rural energy fund which is supported by the Energy Sector Assistance Program (ESAP). Micro hydro depends on water 
and height for power generation. Non climatic and climatic factors that can alter the water flow are upcoming problems for the sustainability of the existing micro hydro power plants.

Table 1.1 below gives a simple overview of the poverty reduction impacts of micro hydro in different sectors.

Table 1.1 Poverty Reduction Impact (PRI) of Micro Hydro Energy (source: AEPC)

\begin{tabular}{|l|l|l|l|l||}
\hline $\begin{array}{l}\text { Poverty Reduction } \\
\text { Indicator }\end{array}$ & $\begin{array}{l}\text { PRI in Household } \\
\text { sector }\end{array}$ & $\begin{array}{l}\text { PRI in Industrial } \\
\text { Sector }\end{array}$ & $\begin{array}{l}\text { PRI in Commercial } \\
\text { Sector }\end{array}$ & $\begin{array}{l}\text { PRI in Social } \\
\text { Sector }\end{array}$ \\
\hline $\begin{array}{l}\text { Security (Income, } \\
\text { employment credit) }\end{array}$ & $\checkmark$ & $\checkmark$ & $\checkmark$ & $\checkmark$ \\
\hline $\begin{array}{l}\text { Knowledge and } \\
\text { Information }\end{array}$ & $\checkmark$ & & & $\checkmark$ \\
\hline Health & $\checkmark$ & & & $\checkmark$ \\
\hline Drudgery Reduction & $\checkmark$ & & & \\
\hline Empowerment/inclusion & $\checkmark$ & & & \\
\hline Gender Equity & $\checkmark$ & & & $\checkmark$ \\
\hline Access to Services & & & & \\
\hline $\begin{array}{l}\text { Environmental } \\
\text { Sustainability }\end{array}$ & & & & \\
\hline
\end{tabular}

"Sustainability of development refers to ensuring a high reliability of meeting future demands without compromising on the hydrologic, environmental and physical integrity" (Mujumdar, 2008). The climate change is further increasing the complexity of the infrastructure projects like energy project. Hydroelectric plants are highly dependent on predictable runoff patterns. Therefore, increased climate variability, which can affect frequency and intensity of flooding and droughts, could affect Nepal severely. In 2007 the International Energy Agency estimated that US\$22 trillion of investment in energy infrastructure would be needed by 2030 , largely in developing countries. This has clearly explained that there is a need of neat climate risk study in any vulnerable community. As freshwater resources will likely become more constrained in the future, this will limit electricity and energy supply, therefore water efficiency must be considered in energy planning (Merce\& Carrillo, 2009). For the proper implementation the institutional framework give the best efficient and fruitful result. Figure 1.3 below briefs about the institution supports for the implementation agency of Micro hydro Development in the government structure.

\section{Sustainable Development and energy:}

Sustainable development (SD) is a pattern of resource use that aims to meet human needs while preserving the environment so that these needs can be met not only in the present, but also for generations to come (sometimes taught as ELF-Environment, Local people, Future) (Wikipedia). SD requires energy which should be sustainable but the resources should be efficient too (Rosen \& Dincer, 2001). In rural areas because of lack of grid and the topography of Nepal, MH is very appropriate. The technology is now a mature technology that has benefited from substantial improvements over the past 30 years (Barnett, 2000). The natural processes are usually heavily influenced by the capacity to manage freshwater resources; that is, the management capacity plays an important role in sustainable development and use of water resources. Particularly, Figure 1.4 elaborates that there are four main components that need to be addressed when planning a sustainable development: water, energy, land use, and policy (Adams \& Younos, 2008). 


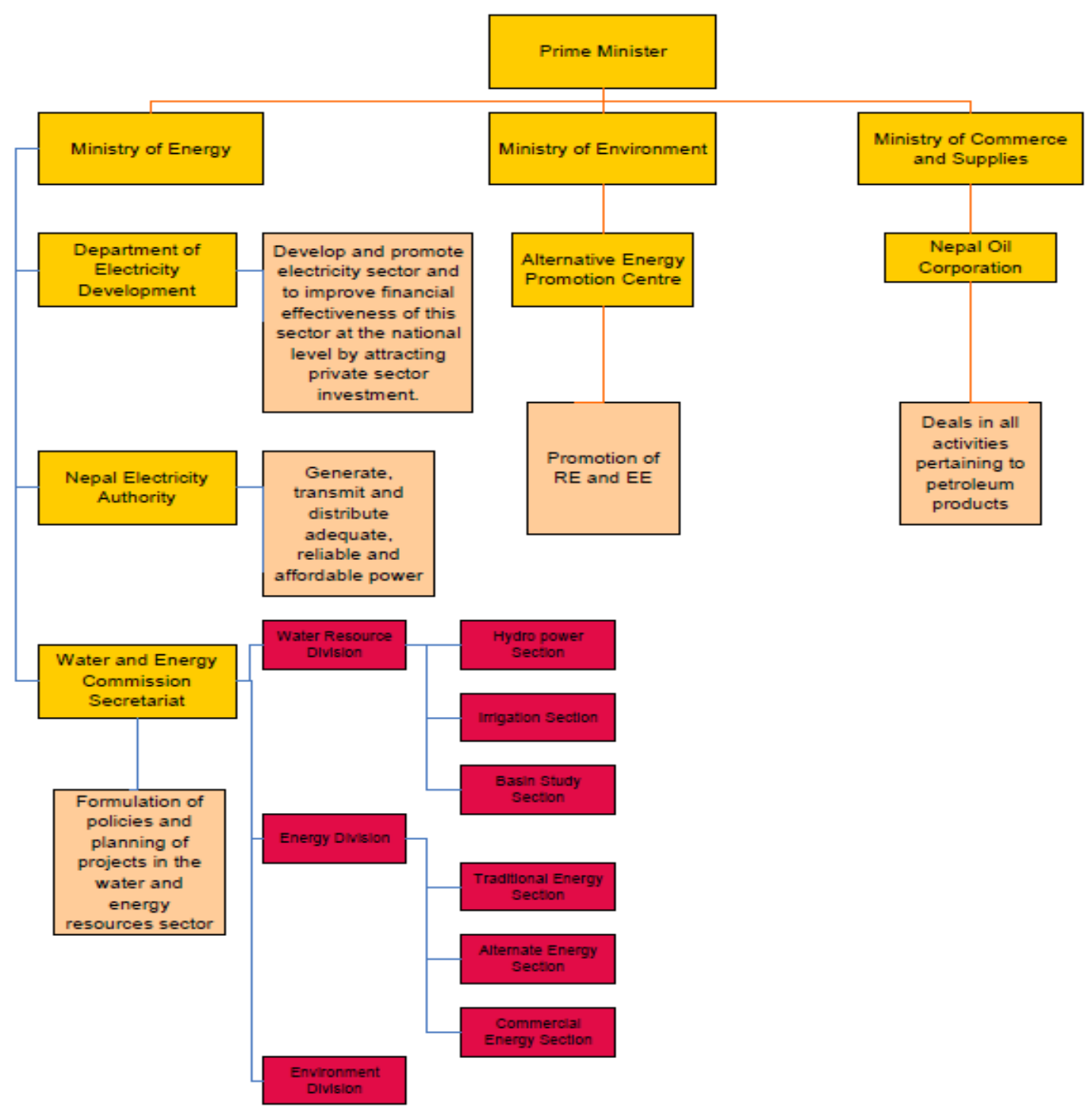

Fig 1.3 Institutional Framework for Micro hydro Development (Source: Banerjee, Singh, \& Samad, 2010)

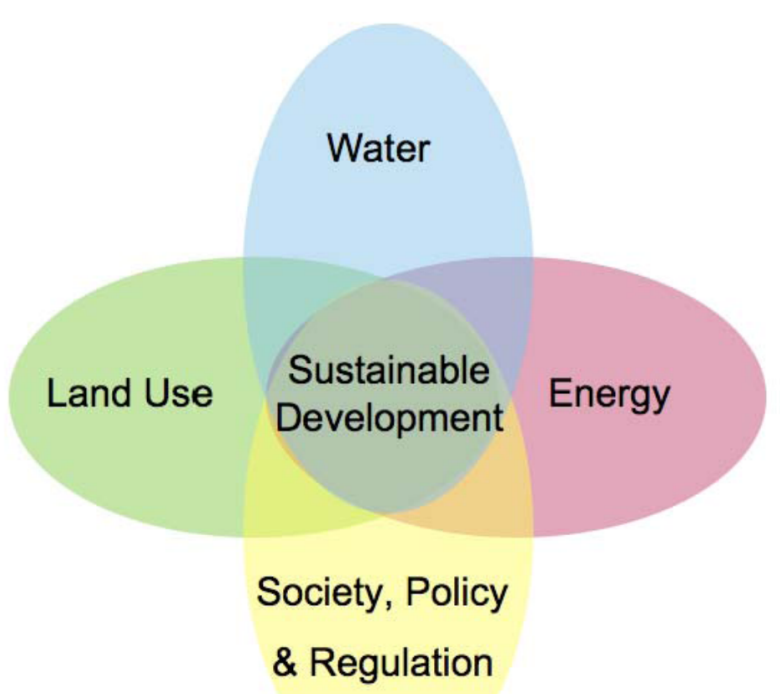

Fig 1.4 Sustainable Development Venn diagram (Adams \& Younos, 2008) 
Micro hydro energy is dependent on water resources. Energy and water for sustainable development depend not only on supply choices, but also on how these choices are implemented. Conflicts can occur due to the different water uses, and unless the legal and administrative framework for resolving these competing needs is adequate the power scheme operator is left in an untenable situation, so in the sustainability guidelines from the International Hydro Power Association, Water management legislation and policies, including licenses, water management plans and water quality standards is one of the process to ensure compliance (IHA, 2004).

\section{Research methodology}

Information collected from a set of questions which was done at an operator level and then information collected from secondary data on climate change and other non climatic factor affecting water availability was analyzed and then conclusions were drawn. The interviewed VDCs were selected so that overall area in the Lalitpur districts could be carried out. Only one VDC were not included because of the remoteness and lack of time. The indigenous knowledge of the operators is important for decision making. Indigenous knowledge has value not only for the culture in which it evolves, but also for scientists and planners striving to improve conditions in rural localities. Following figure 2.1 is the tracing path for the study and various tools list below were used.

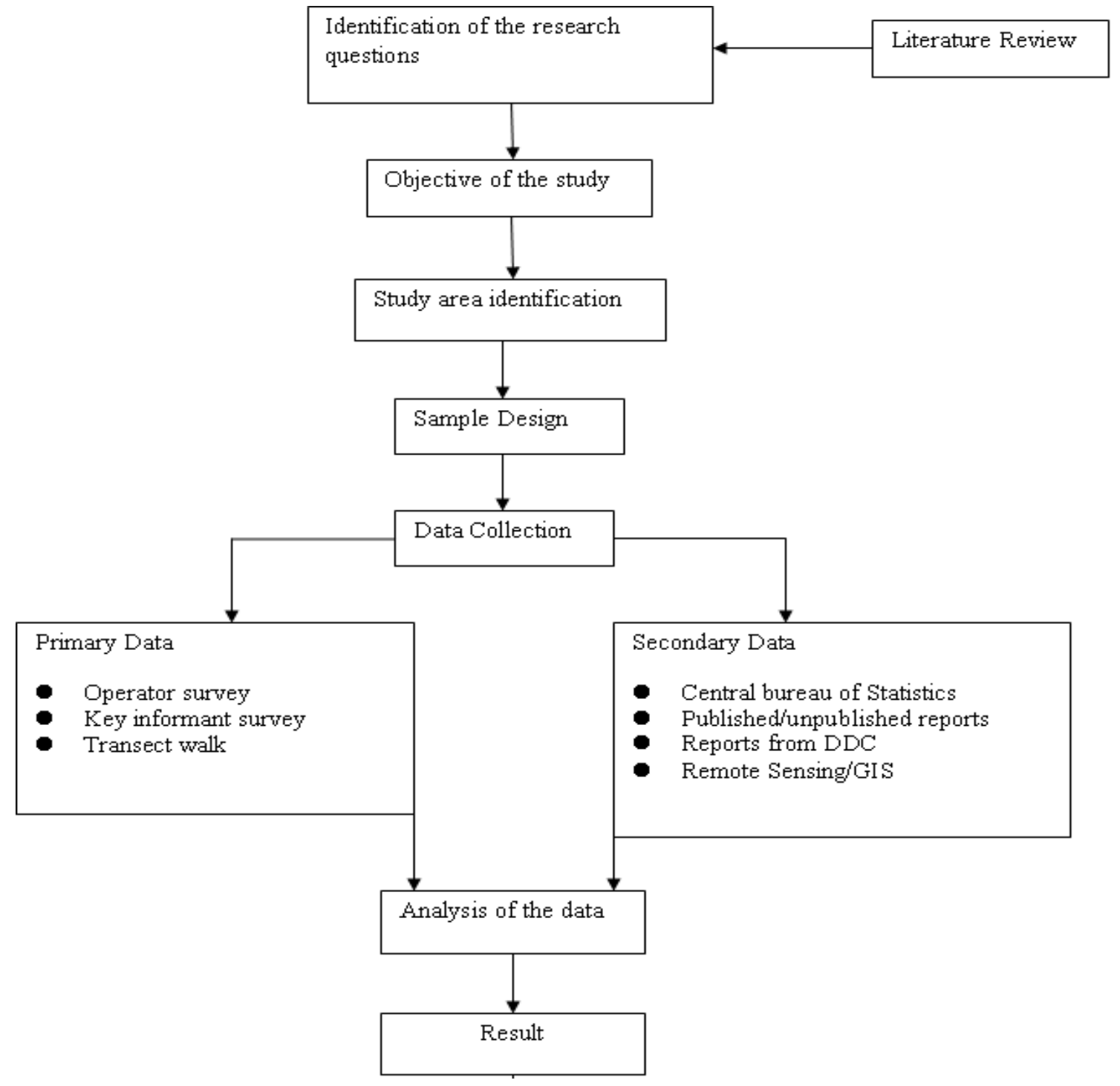

Fig 2.1 Research Methodology framework. 
The data retrieved from the questionnaire survey was processed using SPSS (Statistical Package for the Social Sciences) 16 version. Analysis of completed questionnaire was done to assure that the data are accurate, consistent with the data gathered, uniformly entered and have been arranged to facilitate coding and tabulation. SPSS is a computer program used for survey authoring and deployment, data mining, text analytics, statistical analysis, and collaboration \& deployment (Wikipedia). Various tables related to operators perception was done using SPSS tool. Some of the analyses require chi square and $\mathrm{t}$ test which were also analyzed from SPSS tool and MS Excel respectively. The chi square statistic is used to investigate whether distributions of categorical variables differ from one another (Wikipedia). CRU data were extracted from GIS (Geographical Information System) software and was processed in MS excel. The climate data was analyzed in the Microsoft office excel-2007. An analytical test that is t-test was used in studying the trend of precipitation. The $t$ test was carried with the help of MS excel.

The Pearson correlation was done for analysis. Correlation is the relationship between two variables, is closely related to prediction. The greater the association between variables, the more accurately we can predict the outcome of events (Micro Biology Bytes). The Pearson's correlation is used to find a correlation between at least two continuous variables. The value for a Pearson's can fall between 0.00 (no correlation) and 1.00 (perfect correlation)(SPSS Tutorial). Other factors such as group size will determine if the correlation is significant.

\section{Results and discussion}

Operators are the people who are responsible for the overall maintenance and operation of the micro hydro plants. They are acquainted with the daily water availability of the site. Since majority of the operators were engaged in agriculture, they had a better understanding of the changes felt in the climate variability and water availability. The micro hydro is also providing electricity for agro industry in many villages, which making easy for villagers for agro processing. There are six micro hydro stations which are currently closed.

\subsection{Study of water availability change:}

The water availability change can be due to climatic changes and also from the non climatic changes.

\subsubsection{Climatic Change:}

A total of 25 operators' were interviewed. The major occupation of the respondents is shown inFigure3.1.

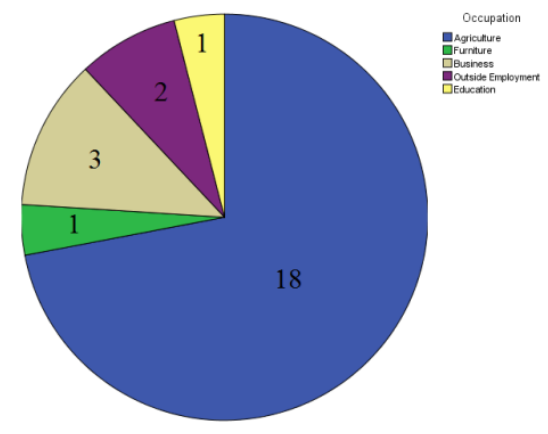

Fig 3.1 Occupation of the respondent in numbers

Majority of the operators are also engaged in agriculture (figure 3.1). The local operator who are also engaged in agriculture, in contrast to the "eagle's eye view" of the high science of satellites, provide a "toad's eye view" rooted in the civic science of traditional knowledge and on the site observation (NCVST, 2009).Many literatures are available to study the climate change analysis in Nepal. For the 
study analysis of the CRU (Climate Research Unit) data is analyzed. CRU gives precipitation data of about 2.5 degree*3.75degree grid. This results in two grid values of the site. Both of them are shown in the following diagram (Grid A and Grid B).

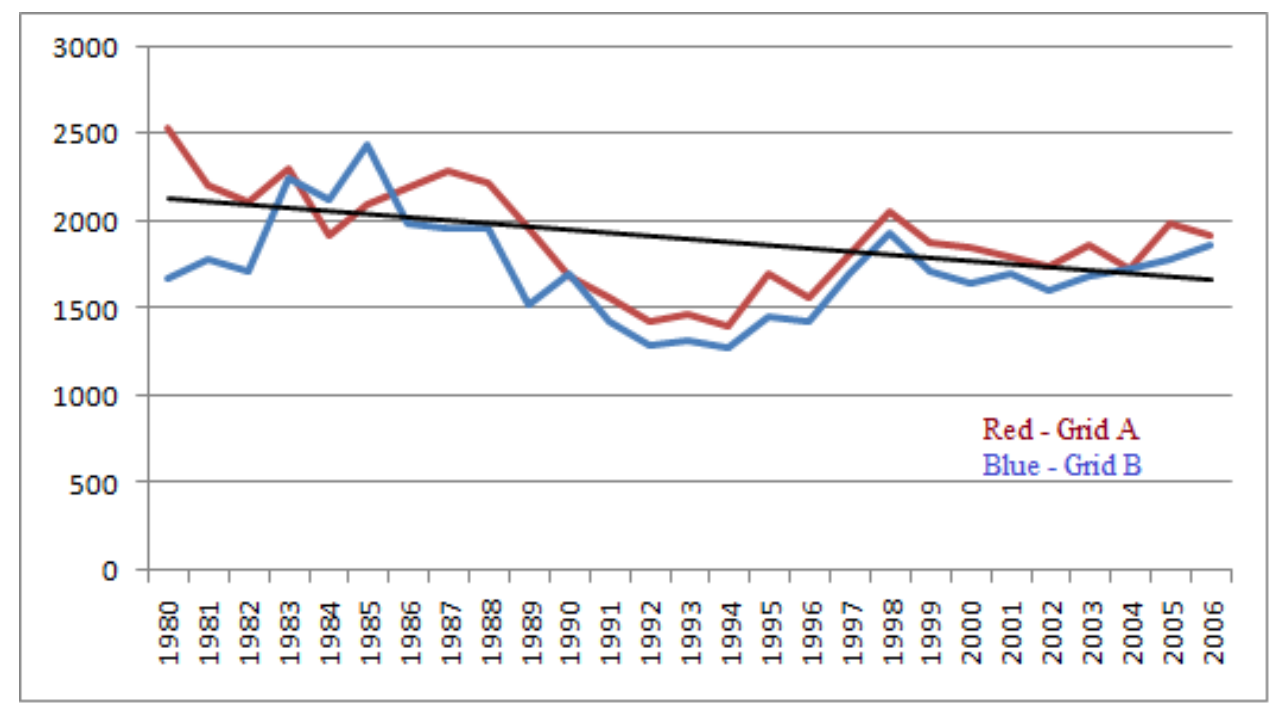

Fig 3.2 Precipitation of the Lalitpur District (source: DHM 2010).

In figure 3.2, it is seen that there is a decreasing trend in the precipitation of the area (trend line). The change in rainfall pattern has occurred in a significant manner which is depicted by the value which is 0.034 , significant at $95 \%$ C.I ( $\mathrm{t}$ test). This explains that the precipitation is changing.

Operators Perception in climate change:

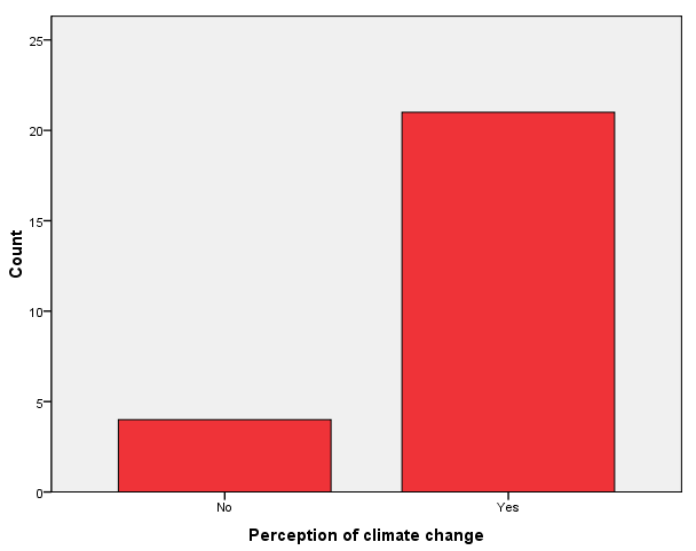

Fig 3.3 Perception of climate change of the operators

The Fig 3.3 gives the perception of the operators in Lalitpur area. As in the figure there are 21 operators who perceive climate change, 4 operators who are unaware. 
Table 3.1 Perception of climate change

\begin{tabular}{|c|c|c|c|c|c|c|}
\hline \multirow{2}{*}{$\begin{array}{c}\text { Perceive } \\
\text { Climate } \\
\text { change }\end{array}$} & $\begin{array}{c}\text { Do not } \\
\text { Perceive } \\
\text { Climate } \\
\text { change }\end{array}$ & \multicolumn{2}{|c|}{$\begin{array}{c}\text { Perceive Temperature } \\
\text { change }\end{array}$} & \multicolumn{2}{|c|}{$\begin{array}{c}\text { Noticed any changes } \\
\text { In Temperature }\end{array}$} \\
\cline { 3 - 7 } & Yes & No & Increased & Decreased & $\begin{array}{l}\text { No } \\
\text { Change }\end{array}$ \\
\hline $84 \%$ & $16 \%$ & $88 \%$ & $12 \%$ & $88 \%$ & $8 \%$ & $4 \%$ \\
\hline
\end{tabular}

The figure 3.3 shows that the perception of climate change in the operators is high in the region. They were able to know about climate change from the news. Radios are commonly used by the people in the region at the lighting hours. Batteries are also commonly used by the locals in the radios. The use of Televisions is increasing in Lalitpur. Further the operators are also feeling that the temperature is increasing in the area. If compared with the global trend there has been an increase in temperature.

\section{Overall surveyed Climatic factor in the region}

Table 3.2 Descriptive Statistics

\begin{tabular}{|l|c|c|c|c|c|}
\hline & $\mathrm{N}$ & Mean & Std. Deviation & Minimum & Maximum \\
\hline $\begin{array}{l}\text { 1. } \begin{array}{l}\text { perception of climate } \\
\text { change }\end{array} \\
\text { 2. } \begin{array}{l}\text { change in water } \\
\text { availability }\end{array}\end{array}$ & 25 & 0.88 & 0.33 & 0 & 1 \\
3. change in timing & 25 & 0.92 & 0.27 & 0 & 1 \\
4. change in thunder storm & 25 & 0.68 & 0.47 & 0 & 1 \\
5. change in temperature & 24 & 0.92 & 0.28 & 0 & 1 \\
6. \begin{tabular}{l} 
rainfall pattern \\
\hline
\end{tabular} & 25 & 0.16 & 0.37 & 0 & 1 \\
\hline
\end{tabular}

In table 3.2 the respondent responded the question by yes/no question. This is the basic feature of the data in water availability from the questionnaire.

\section{Correlation of different parameters using SPSS:}

The data from the questionnaire were entered in the SPSS- 17.0 and various correlations were examined between the variables used in this study. The variables were perception about the change in climate, perception about the change in rainfall pattern, perception about the change in temperature, perception regarding the change in water availability, Increase/decrease in rainfall amount, changes in flash flood, Increase/decrease in temperature. The correlation was examined at the $5 \%$ level of significance and as a result only two relations were found statistically significant although the correlation coefficients were not so strong (C10 Elementary Statistics for Political Research). 
- $\quad$ Note that a relationship can be strong and yet not significant

- $\quad$ Conversely, a relationship can be weak but significant

Table 3.3 Correlations of various parameters in climate change

\begin{tabular}{|c|c|c|c|c|c|c|}
\hline & & $\begin{array}{l}\text { change in } \\
\text { rainfall } \\
\text { amount }\end{array}$ & $\begin{array}{c}\text { perception } \\
\text { of climate } \\
\text { change }\end{array}$ & $\begin{array}{l}\text { change in } \\
\text { flash flood }\end{array}$ & $\begin{array}{c}\text { change in } \\
\text { thunder } \\
\text { storm }\end{array}$ & $\begin{array}{l}\text { change in } \\
\text { temperature }\end{array}$ \\
\hline \multirow{3}{*}{$\begin{array}{l}\text { change in rainfall } \\
\text { amount }\end{array}$} & $\begin{array}{l}\text { Pearson } \\
\text { Correlation }\end{array}$ & 1 & 0.21 & 0.04 & 0.38 & -0.17 \\
\hline & Sig. (2-tailed) & & 0.32 & 0.82 & 0.05 & 0.41 \\
\hline & $\mathrm{N}$ & 25 & 25 & 25 & 25 & 24 \\
\hline \multirow{3}{*}{$\begin{array}{l}\text { perception of } \\
\text { climate change }\end{array}$} & Pearson & 0.21 & 1 & 0.12 & 0.27 & $0.45^{*}$ \\
\hline & Sig. (2-tailed) & 0.32 & 0 & 0.55 & 0.18 & 0.02 \\
\hline & $\mathrm{N}$ & 25 & 25 & 25 & 25 & 24 \\
\hline \multirow{3}{*}{$\begin{array}{l}\text { change in flash } \\
\text { flood }\end{array}$} & $\begin{array}{c}\text { Pearson } \\
\text { Correlation }\end{array}$ & 0.04 & 0.12 & 1 & 0.08 & $0.58^{* *}$ \\
\hline & Sig. (2-tailed) & 0.82 & 0.55 & 0 & 0.68 & 0.01 \\
\hline & $\mathrm{N}$ & 25 & 25 & 25 & 25 & 24 \\
\hline \multirow{3}{*}{$\begin{array}{c}\text { change in thunder } \\
\text { storm }\end{array}$} & $\begin{array}{c}\text { Pearson } \\
\text { Correlation }\end{array}$ & 0.38 & 0.27 & 0.08 & 1 & 0.10 \\
\hline & Sig. (2-tailed) & 0.05 & 0.18 & 0.68 & 0 & 0.62 \\
\hline & $\mathrm{N}$ & 25 & 25 & 25 & 25 & 24 \\
\hline \multirow{3}{*}{$\begin{array}{l}\text { change in } \\
\text { temperature }\end{array}$} & $\begin{array}{l}\text { Pearson } \\
\text { Correlation }\end{array}$ & 0.17 & $0.45^{*}$ & $0.58^{* *}$ & 0.10 & 1 \\
\hline & Sig. (2-tailed) & 0.41 & 0.02 & 0.01 & 0.62 & 0 \\
\hline & $\mathrm{N}$ & 24 & 24 & 24 & 24 & 24 \\
\hline
\end{tabular}

*. Correlation is significant at the 0.05 level (2-tailed).

**. Correlation is significant at the 0.01 level (2-tailed).

Table 3.3 reveals that there is a correlation between change in temperature and change in flash floods. The operators who think that the there is a change in temperature has said that there is a correlating 
change in the flash flood intensity. Similarly there is a correlation between perception of climate change and change in temperature. Correlations from table 3.3:

1. Change in temperature and perception of climate change is significant at $95 \%$ confidence interval and the coefficient is 0.45 .

2. Change in temperature and change is flash flood is significant at $95 \%$ confidence Interval and the coefficient is 0.58 .

The correlation between the perception regarding climate change vs. change in temperature is found to be 0.45 ,which means when people perceive that climate is actually changing from past few years at the same time the they also perceive that temperature is also changing and is increasing; statistically both perceptions are increasing together at the rate of 0.45 . This also can be alternatively expressed as the strength of their variances is 0.45 . Similarly correlation between change in temperature and change in flash flood is found 0.58 , which means that temperature is changing in the past few years at the same time they also perceive changes in rate of flash flood occurrence. This is increasing at the rate of 0.58 .

\subsubsection{Non climatic changes:}

The MHP mostly uses small spring streams for power generation. These springs can be disturbed by other development like road network and other infrastructure (field investigation 2011). The road networks are often constructed between the water passage from the springs, this kind of development often changes the course of the water. There are many cases that there are road construction without prior consultation of the local people or with only engineering aspects in mind, these kind of development can ruin the project or complicate the water availability

Some of the proposed plan development by Lalitpur District Development Committee (DDC report 2002 A.D), which are interlinks with water resource in the area.

a. The income from animal husbandry per person to increase from Rs. 7094 to Rs. 10,587

b. The water supply to the people would increase from $60.93 \%$ to $95.3 \%$

c. All the people will have road facilities within a walking distance of $3 \mathrm{hrs}$.

d. There will be decrease of $4 \%$ in Landslides and soil erosion.

e. To electrify 14 more V.D.Cs.

The above mentioned development proposed by the DDC is having direct and indirect affect in the water availability. According to the planning officer in the Lalitpur District Development Committee, there is no study of interlink between two development when the plan is commenced. He further explained that even there are adequate funds for monitoring there is no monitoring exercise done for these plants (personal conversation with the planning officer May 2011). Further he said that there is also no land use map of the districts. The land use map helps to conserve the environment. This has increased settlements in the forests area. Similarly resources distribution is also affected. For the better implementation of the infrastructure there must be monitoring exercises in the sites by the concerned authorities. None of the plants are monitored by any agencies (Field survey March 2011).

\subsection{Study of energy and water availability:}

Water availability has affected the generation of the electricity. The percentage of people who have perceived that there is a change in the water availability, increase/decrease in water availability in the rivers/springs, rainfall pattern irregular/regular, and changes in rain timings (previously occurring rain time) is shown in Table 3.4. 
Table 3.4 Perception of operator's (Rainfall and Flash flood)

\begin{tabular}{|c|c|c|c|c|c|}
\hline \multicolumn{2}{|c|}{$\begin{array}{c}\text { Change in Timing of } \\
\text { rainfall }\end{array}$} & \multicolumn{2}{c|}{$\begin{array}{c}\text { Changes in Rainfall } \\
\text { Amount }\end{array}$} & \multicolumn{2}{c|}{ Changes in Flash Flood. } \\
\hline Yes & No & Increase & Decrease & Yes & No \\
\hline 92 & 8 & 26 & 76 & 80 & 20 \\
\hline
\end{tabular}

(Note: All values are expressed in percentage)

(Source: field survey March 2011)

Using SPSS 17 to correlate the rainfall increase/decrease and effect of climate change in energy production, the value of the chi-square was 0.055 not significant at $95 \%$ C.I. This means that at the current stage the effect of climate change is not so significant in micro hydro power water availability. The calculations do not show the relation with the operator's perception because of lack of adequate data.

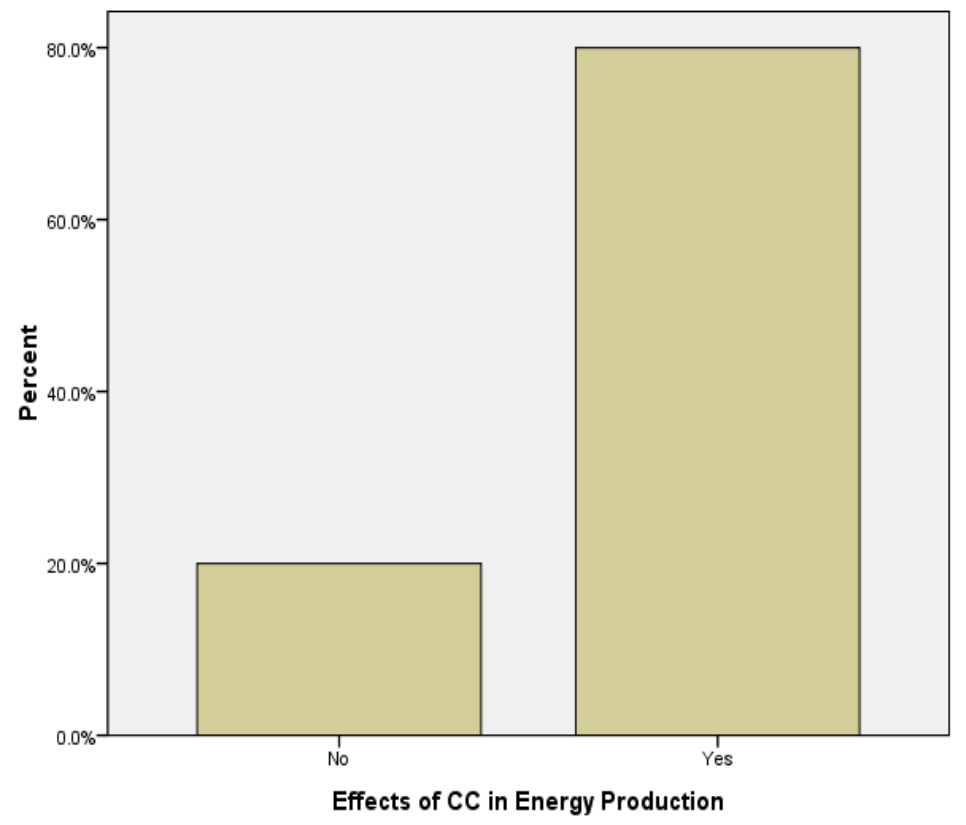

Fig 3.4 Effects of Climate change in energy production

Figure 3.4 elaborates that the operators have already experienced effects of water availability change in energy production. The water availability challenge have limited the electricity usage to the local people. Some operator said that they run the plant for only $2 \mathrm{hrs}$ in the peak time because of lack of water in the dry seasons (field survey, 2011). However the demand of electricity in the sites are increasing as use of electrical appliances (TV, Radios) are increasing highly according to the operators.

Flashflood do not help to recharge the ground aquifers. As the operators percieve extensive flashflood increment, there is a distribution changes in the rainfall amount in the rainy seasons. The problem of less electricuty production will further aggravate as there is a prediction of changing rainfall amount by the operators in the region. Since the micro hydro station were set up in different years, the 
operators had different view of how energy production is depleting (If yes why and if no why). These are the qualitative indicators which were percieved by the operators.

Table 3.5 Views of operator on decreasing energy production

\begin{tabular}{|l|l|}
\hline \multicolumn{1}{|c|}{ YES } & \multicolumn{1}{|c|}{ NO } \\
\hline - $\begin{array}{l}\text { Change in the duration of electricity } \\
\text { production. }\end{array}$ & $\bullet \quad$ It uses water from the river not streams \\
- & Damming of the water takes time. \\
- Prolonged dry effects (No adequate rain, &
\end{tabular}

\section{Adaptation measures undertaken}

Out of the 25 micro hydro operators' only one operator claims that he has started adaptation to such problems. He says that is doing forestation programs and is creating community awareness in his community. However 13 operators claimed that their community is doing forestation programs (community forest included) in their respective V.D.Cs.

\subsection{Awareness of Sustainable Development and sustainability of the plants}

The figure 17 has knowledge of sustainable development in the $\mathrm{x}$-axis and technology sustainable or not in the z-axis. The table further elaborates that majority of the operators do know about sustainable development and when further questioned about the plant's sustainability very less have said that the plant is not sustainable.

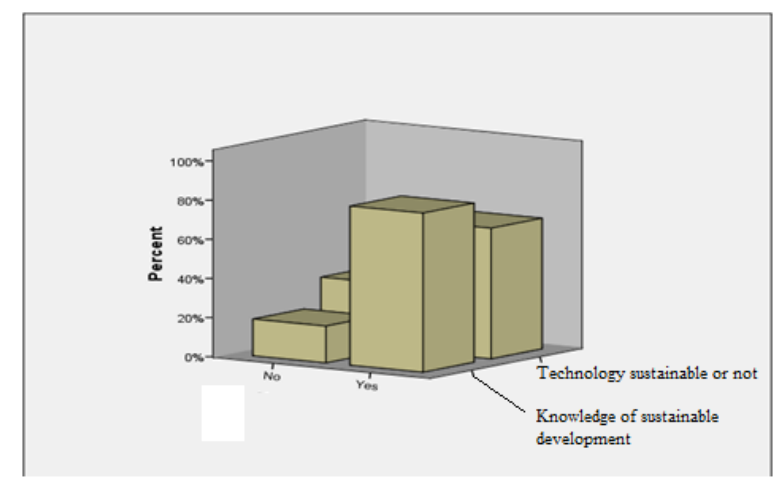

Fig 3.5 Operator's knowledge of Sustainable Development

Majority of the operators say that the production of the electricity is already degrading. There has been a sharp depletion of production hours in the recent years. Since there are no log books and the operators do not know how to measure the electricity produced, they explained in terms of water availability the depletion of electricity production. 


\section{Operators view for Sustainability of the plants:}

The ideas of the operators for the sustainability of the plants are as follows:

1. Increasing production

2. Awareness

3. Economic supports

4. Technical support

5. Storage of water (small dams)

6. Power saving

7. Follow rules and regulation

8. Construction of other plants for more power

9. Afforestration

Table 3.6 Correlation with other different parameter:

\begin{tabular}{|c|c|c|c|c|}
\hline & & $\begin{array}{c}\text { knowledge } \\
\text { about SD }\end{array}$ & $\begin{array}{c}\text { campaigning of } \\
\text { forest }\end{array}$ & $\begin{array}{l}\text { practicing } \\
\text { adaptation }\end{array}$ \\
\hline \multirow{3}{*}{ knowledge about SD } & Pearson Correlation & 1 & $0.39^{*}$ & 0.12 \\
\hline & Sig. (2-tailed) & & 0.05 & 0.58 \\
\hline & $\mathrm{N}$ & 25 & 25 & 25 \\
\hline \multirow{3}{*}{ campaigning of forest } & Pearson Correlation & $0.39^{*}$ & 1 & 0.19 \\
\hline & Sig. (2-tailed) & 0.05 & & 0.34 \\
\hline & $\mathrm{N}$ & 25 & 25 & 25 \\
\hline \multirow{3}{*}{ practicing adaptation } & Pearson Correlation & 0.12 & 0.16 & 1 \\
\hline & Sig. (2-tailed) & 0.58 & 0.37 & \\
\hline & $\mathrm{N}$ & 25 & 25 & 25 \\
\hline
\end{tabular}

* Correlation is significant at the 0.05 level (2-tailed).

From the table 3.6, suggests that there is a correlation between Knowledge of Sustainable developments of the operators with the campaigning of the forest at the rate of 0.397 and is increasing. This also further elaborates that the operators feel that with the depletion of the forest the water resources is also depleting. 


\subsection{Study of electricity usage}

There is an uncertainty in the production of electricity because there is an uncertainty of the water availability. There are no timers to register the hours of operation in micro hydro systems. The micro hydro schemes have operator who maintain the micro hydro and are responsible for shutting down and operating the micro hydro plants. None of them in Lalitpur keep log books. A study done by World Bank/AEPC 2009 cited in (Banerjee, Singh, \& Samad, 2010) states that the average domestic consumption is $22.83 \mathrm{kWh} /$ month in Central Nepal. Out of 893 household in which the 25 micro hydro stations provides electricity, there are 15 household which use solar PV for lighting.

Table 3.7 Cost paid by the customer

\begin{tabular}{|l|c|c|c|c|}
\hline VDC Ward no & Rs/Month & KW & House hold & Money/hh \\
\hline Gotikhel 2 & 100 & 15 & 140 & 14000 \\
\hline Manikhel 3 & 40 & 3 & 32 & 1280 \\
\hline Gotikhel 9 & 20 & 6 & 80 & 1600 \\
\hline Gotikhel 2 & 30 & 3 & 32 & 960 \\
\hline Kaleswor 5 & 20 & 3 & 34 & 680 \\
\hline Kaleswor 1 & 25 & 5 & 25 & 625 \\
\hline Chandanpur 4 & 20 & 3 & 32 & 640 \\
\hline Kaleswor 2 & 20 & 1.5 & 13 & 260 \\
\hline Gotikhel 6 & 20 & 2 & 17 & 340 \\
\hline Ikudole 7 & 25 & 3 & 30 & 750 \\
\hline Gotikhel 8 & 100 & 3 & 6 & 600 \\
\hline Sankhu 7 & 20 & 2.5 & 23 & 460 \\
\hline Bukhel 9 & 10 & 3 & 34 & 340 \\
\hline Bukhel 5 & 30 & 4 & 56 & 1680 \\
\hline Bukhel 7 & 10 & 2.2 & 23 & 230 \\
\hline Bukhel 7 & 75 & 3 & 13 & 975 \\
\hline Manikhel 2 & 100 & 1.5 & 15 & 1500 \\
\hline Gotikhel 6 & 35 & 2 & 24 & 840 \\
\hline Manikhel 8 & 50 & 3 & 26 & 1300 \\
\hline Gimdi 5 & 80 & 2.5 & 35 & 2800 \\
\hline Gimdi 1 & 50 & 11 & 107 & 5350 \\
\hline Gimdi 6 & 50 & 4 & 40 & 7600 \\
\hline Pyutar 3 & 40 & 2.5 & 383 & 1300 \\
\hline Bhattedanda 6 & 50 & 3 & 91270 \\
\hline Total & 995 & 96.7 & & \\
\hline Avg. Household & & & & \\
\hline
\end{tabular}


From Table 3.7:

- The average expenditure in micro hydro per month is about $50 \mathrm{Rs} /$ month.

- $\quad$ The average power used per household is $110 \mathrm{~W}$ (total $\mathrm{KW} / \mathrm{HH}$ )

- $\quad$ The average hours of electricity usage is 7 hrs. (Power * Time (time usage per day * Month) $=$ Avg. Domestic Consumption (22.83 kWh/Month))

All of the aspects of a project must be considered in the planning process and should be covered effectively. The neglect of any one aspect can distort the whole program, cause it to slow down or its costs to rise, or even cause it to fail completely (DFID/ESD, 1999). Water is the most important need of the micro hydro station. As stated by the planning officer, interlink study is not done in planning process of water has a great threat in the sustainability of the plants as the resources is depleting. The micro hydro does not consume water; it only uses the water current and height for energy production. This states that better management is the key for sustainable water management and also energy production. The increase in flashfloods also contributes towards the breaking down of the micro hydro power plants from direct exposing from the heavy rain and sedimentation problem. However the majority of the operators think that the breaking of the plants is normal like before because in every site there is a small dam is constructed for water to be filtered from sedimentation. This is very important as water can spoil the turbine reducing the efficiency.

\section{Conclusions and findings}

The study conducted in Lalitpur district revealed some interesting facts. There are about 33 micro hydro stations in the site. This study was done only in 25 working micro hydro stations in the region. Out of the 33, six micro hydro stations are shut off mainly due to lack of community management and grid connection. The study made the following conclusions:

- The majority of the operator perceives climate change and correspondingly perceives the change in water timing and availability altering the hydrology and they are already facing problem now and it might go worse in the years to come.

- Change in water availability is one of the prominent issues in micro hydro development. The construction of micro hydro is carried out for lighting but lack of adequate water has shortened the lighting time and decrease in the expected generation.

- Not only climatic factors are responsible for less water availability but other non climatic factors are also equally responsible for low discharge in the streams. The lack of the interlink planning between different water use complicates the water resources and increases conflicts.

- $\quad$ Sustainable development is a broad concept so further research is necessary for the overall sustainability of the systems. There is a need of better interdisciplinary water resources management planning and integrating in the energy development to increase the sustainability of these plants with respect to increasing demand and environmental problems. 


\section{References}

1. A. Nyong, F. A., "The value of indigenous knowledge in climate change mitigation and adaptation strategies in the African Sahel”, Mitig Adapt Strat Glob Change, (2007).

2. Barnett, S. K., "Best Practices for Sustainable Development of Micro Hydro in Developing Country”, DFID/ITDG, (2000).

3. Cai Yao, S. Y., "Regional summer precipitation events in Asia and their changes in the past decades", JOURNAL OF GEOPHYSICAL RESEARCH, VOL. 113 , (2008)

4. Dincer, I., "Renewable energy and sustainable development: a crucial review", Renewable and Sustainable Energy Reviews, (1999)

5. Gill, A., Mosley, P., \& Fulford, D. J., "Community Micro-Hydro in LDCs Adoption, Management and Poverty Impact Project”. DFID; ESD, (1999)

6. Lacayo, A. I., "Off-grid Energy in Rural India: Policy Recommendations for effective UN projects", (2006)

7. Merce, A., \& Carrillo, R., “Water: A key resource in energy production”, Energy Policy, (2009).

8. NCVST, "Vulnerability through the eyes of vulnerable", Institute for Social and Environmental Transition-Nepal (ISET-N), (2009).

9. Rosen, M. A., \& Dincer, I., "Exergy as the confluence of energy, environment and sustainable development” Exergy , (2001).

10. Ryan Bartlett, L. B., "Climate change impacts and adaptatio", Internation Water Management Institute, (2010)

11. Nepal Govinda, "Study on Analysis of Rural Energy Programs with Respect to Their Linkages with Poverty Reduction”, AEPC, April 2005

12. Y.P. Caia, G. H, "Investigation of public's perception towards rural sustainable development based on a two-level expert system”. Expert Systems with Applications , 8910-8924, (2009). 